
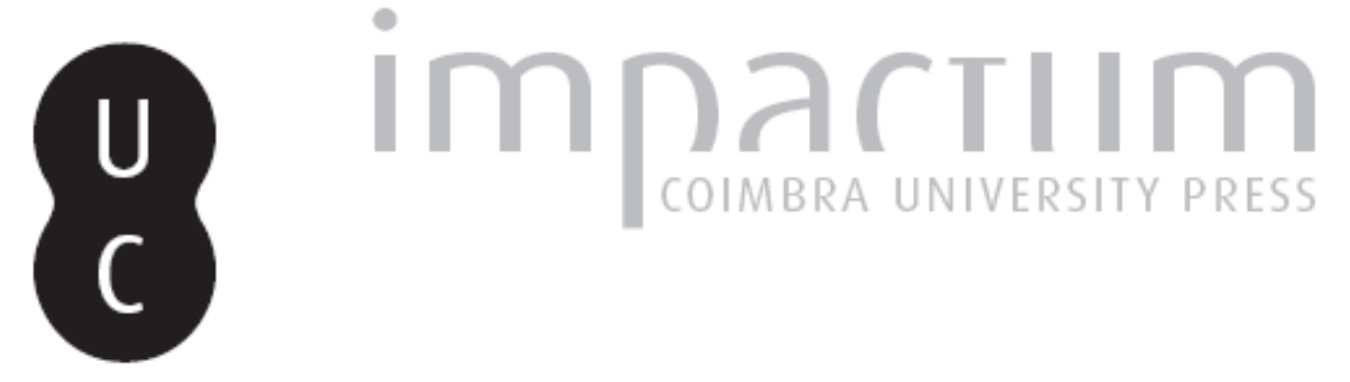

A visão da Igreja Católica e a constituição da Europa na Época Contemporânea

Autor(es): $\quad$ Ribeiro, Maria Manuela Tavares

Publicado por: Imprensa da Universidade de Coimbra

URL persistente:

URI:http://hdl.handle.net/10316.2/43730

DOI:

DOI:https://doi.org/10.14195/2183-8925_24_17

Accessed : $\quad$ 26-Apr-2023 14:16:55

A navegação consulta e descarregamento dos títulos inseridos nas Bibliotecas Digitais UC Digitalis, UC Pombalina e UC Impactum, pressupõem a aceitação plena e sem reservas dos Termos e Condições de Uso destas Bibliotecas Digitais, disponíveis em https://digitalis.uc.pt/pt-pt/termos.

Conforme exposto nos referidos Termos e Condições de Uso, o descarregamento de títulos de acesso restrito requer uma licença válida de autorização devendo o utilizador aceder ao(s) documento(s) a partir de um endereço de IP da instituição detentora da supramencionada licença.

Ao utilizador é apenas permitido o descarregamento para uso pessoal, pelo que o emprego do(s) título(s) descarregado(s) para outro fim, designadamente comercial, carece de autorização do respetivo autor ou editor da obra.

Na medida em que todas as obras da UC Digitalis se encontram protegidas pelo Código do Direito de Autor e Direitos Conexos e demais legislação aplicável, toda a cópia, parcial ou total, deste documento, nos casos em que é legalmente admitida, deverá conter ou fazer-se acompanhar por este aviso.

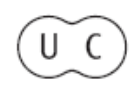



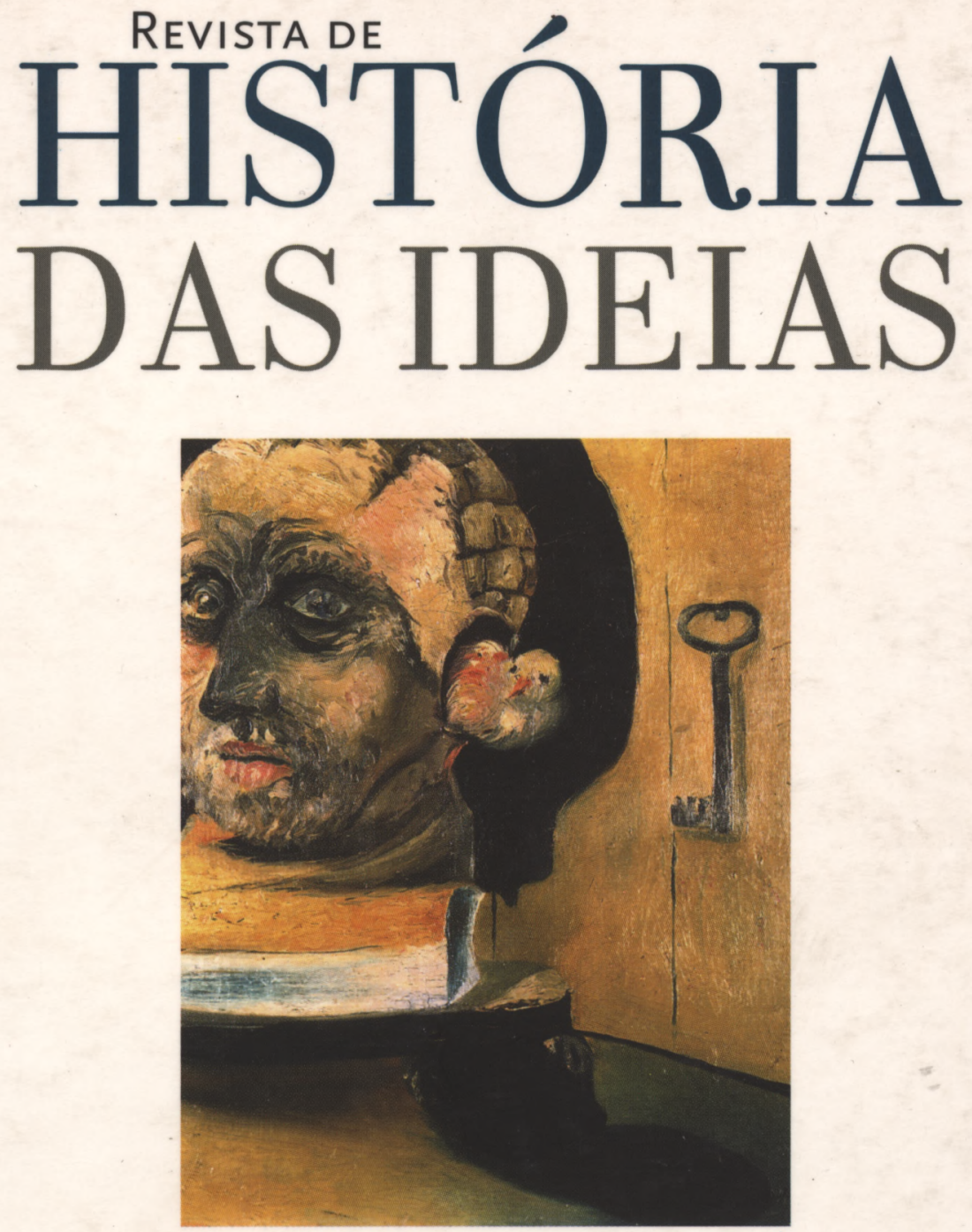

OS INTELECTUAIS E OS PODERES

Volume 24, 2003

INSTITUTO DE HISTÓRIA E TEORIA DAS IDEIAS

Faculdade de Letras da Universidade de Coimbra 


\section{A VISÃO DA IGREJA CATÓLICA E A CONSTRUÇÃO DA EUROPA NA ÉPOCA CONTEMPORÂNEA}

\section{Introdução}

A concepção de um "bem comum europeu", a construção da paz e os sentimentos de aliança e de solidariedade, para além de preocupações de ordem política, económica e social, inspiraram personalidades políticas como Robert Schuman, Konrad Adenauer, Alcide De Gasperi, Jean Monnet, entre muitos outros, mas orientaram também a visão vaticana, de Pio XII a João Paulo II, bem assim como a reflexão dos representantes da alta hierarquia da Igreja Católica sobre o presente e o futuro da Europa, uma reflexão perspectivada na ligação intrínseca entre o cristianismo e o universalismo.

O conceito de Europa é polinuclear, a sua "unidade" é plural. No decurso da sua história milenária, ela enriqueceu-se com a pluralidade das suas tradições, das suas experiências, e assim acumulou um património único, património que tem as suas raízes na cultura greco-romana, na cultura cristã e no humanismo secularizado. Ora, no discurso da Igreja Católica (no dos pontífices e do episcopado, que é o que aqui nos ocupa) esse ideal ético e religioso é um agente dinâmico no diálogo entre nações,

* Faculdade de Letras da Universidade de Coimbra e Vice-Coordenadora do Centro de Estudos Interdisciplinares do Século XX da Universidade de Coimbra (CEIS20). 
entre igrejas, entre religiões, e na construção de uma "civilização nova" através de uma reevangelização sentida como indispensável e do "encontro de culturas", sustentáculos da unidade da Europa na sociedade secularizada.

É neste quadro que procuraremos desenvolver algumas considerações sobre a posição da Igreja Católica, mais concretamente sobre as suas motivações, os seus objectivos e as suas interrogações, tais como: que Europa?, que unidade da Europa?, quais as suas fronteiras?, como construir a paz? que futuro para a Europa alargada? Em suma, que lugar é que ela ocupa na geopolítica pontifical desde Pio XII?

Mas em que medida se pode analisar a relação entre a Santa Sé e a política europeia? Não é ela uma instituição eminentemente espiritual e não tanto política? Não é ela além disso uma instituição de carácter universal e não limitada tão-só à Europa?

Apesar desta sua natureza específica, pode afirmar-se que a Igreja esteve presente na vida internacional do seu tempo. Se se fizer uma síntese retrospectiva da sua actividade no plano internacional, verifica-se que a Santa Sé se revela dotada de um poder sui generis, assente na sua própria dinâmica universalista ${ }^{(1)}$. A finalidade que ela diz perseguir é assumidamente de ordem ética no contexto da ordem jurídica internacional. Assim entendida, o seu poder de acção e de influência decorre alegadamente da sua situação de "neutralidade", logo, na sua perspectiva, não depende das contingências e das competições políticas e do jogo de interesses económicos. É à luz de uma visão globalista dos problemas do mundo que a Igreja define e exerce uma interpelação às nações.

Debater estas questões será uma boa base para se compreenderem as semelhanças e as diferenças que existem nas diferentes perspectivas dos pontífices, bem assim como as ideias que nortearam os representantes da alta hierarquia da Igreja Católica no processo de construção europeia no período pós-Segunda Guerra Mundial.

(1) A universalidade da Santa Sé é sublinhada pela sua participação nas cinco comissões regionais da ECOSOC, o Conselho económico e social das Nações Unidas e não apenas na sua comissão europeia. Cf. Joël-Benoît d'Onorio, "Le Saint-Siège et le Droit International", in Le Saint-Siège dans les relations internationales, sous la direction de Joël-Benoît d'Onorio, Paris, Cerf/Cujas, 1989, p. 58 , nt. 126. 


\section{Universalismo e Europa no discurso de Pio XII}

A exigência de uma refundação da ordem social e internacional europeia à luz dos princípios cristãos, formulada pelo Papa Pio XII, deixa transparecer duas ideias-mestras na visão pontifícia sobre a União Europeia: uma, a construção de uma unidade superior em nome do "bem comum", outra, o postulado de uma identidade cristã a restaurar. Na Europa do pós-guerra, a ambição pontifícia não seria, antes de mais, a de dar à Europa uma unidade interior que lhe permitisse renovar-se, dada a sua vocação cristã de paz e a sua missão civilizadora do mundo?

Alguns dias depois de ter enviado um representante ao Congresso de Haia, em Maio de 1948, Pio XII pronunciou-se publicamente (em 2 de Junho) a favor de uma união europeia e, a 11 de Novembro do mesmo ano, perante uma delegação de defensores do federalismo europeu (UEF), convidava as grandes nações do continente a abstrair das suas grandezas do passado para caminharem no sentido de uma unidade política e económica ${ }^{(2)}$. Não surpreende, portanto, que esta mesma ideia subjaza ao seu discurso de 13 de Setembro de 1952 aos peregrinos de Pax Christi ${ }^{(3)}$. Pio XII reconhece o "espírito europeu", ou seja, a percepção dos valores espirituais comuns, como aliás também refere na alocução de 15 de Março de 1953 aos membros do Colégio da Europa de Bruges, como "um objectivo principal, sem o qual" - afirma - "nada de sólido se poderá construir" (4). É na lógica desta conclusão que, no seu pensamento, é particularmente detectável o ideal de que a Europa é o palco de objectivação da "união continental entre os seus povos"(5). Como julgamos evidente, a referência à Europa "continental" extravasa naturalmente as fronteiras da "Pequena Europa" dos Seis. Isto significa que ela traduz igualmente a concepção de uma Europa supranacional.

(2) "Allocution aux délégués du $2^{\mathrm{e}}$ Congrès International de l'Union européenne des fédéralistes", Documentation Catholique, 1948, cols. 1538-1539. Passamos a citar esta publicação pela sigla D.C..

(3) Veja-se D.C., 1952, cols. 1411-1412.

(4) Veja-se D.C., 1953, cols. 394-395.

(5) "Radiomessage de Noël, 24 décembre", D.C., 1954, cols. 8-9. 
Assim, o Papa acolheu favoravelmente a criação da Comunidade Europeia do Carvão e do Aço (CECA), em 1950, organismo supranacional, encarando-a como via salutar para o enriquecimento não só económico e cultural, mas também espiritual e religioso ${ }^{(6)}$. Pode dizer-se que, entre Maio de 1952, data da assinatura do tratado que instituiu a Comunidade Europeia de Defesa (CED), e Agosto de 1954, data da rejeição deste mesmo tratado pelo parlamento francês, Pio XII revelou um activo empenhamento no processo da construção europeia.

Parte integrante da posição pontifícia, em matéria de organização política, é a manifesta simpatia de Pio XII pelas ideias federalistas "maximalistas", reclamando a instauração de poderes supranacionais ${ }^{(7)}$. O Papa não tinha dúvidas de que as autonomias, as aspirações e preocupações locais se saldavam numa força estimulante na elaboração da desejada unidade federal europeia. Consequentemente, a elaboração dos Tratados de Roma, em Março de 1957, foi seguida com particular atenção pelo Sumo Pontífice que reconheceu a importância e a responsabilidade de uma autoridade política europeia supranacional ${ }^{(8)}$. Não admira, por isso, que o Osservatore Romano se refira à assinatura desses tratados como o acontecimento mais importante e mais significativo da história moderna da "cidade eterna"(9).

Ora, se tudo isto torna claro o seu confessado apoio à integração europeia, não é menos verdade que Pio XII fundamentava esta sua aspiração em pretensões de uma outra ordem que não a das orientações políticas e ideológicas. Compreende-se, deste modo, que essas preocupações com a Europa não devessem, em seu entender, divorciar-se das preocupações universais. Dito por outras palavras, a construção europeia deveria traduzir a ideia de uma Europa cristã, mas não dissociada da

(6) "Discours aux participants du Congrès de l'Europe (présidé par Robert Schuman) le 13 juin 1957", D.C., 1957, cols. 847-848.

(7) "La voix des autonomies locales, leurs aspirations et leurs préocupations constituent un élément à la fois stimulant et pondérateur dans l'élaboration de l'unité fédérale européenne qui se cherche [...] il faut [...] constituer dans l'Europe qui se fait une vaste et solide majorité de fédéralistes qui tiennent pour les principes d'un sain personnalisme" (D.C., 1958, col. 26).

(8) "Discours aux participants du Congrès de l'Europe", D.C., 1957, col. 849.

(9) L'Osservatore Romano, Março 1957. 
edificação de uma comunidade mundial assente nos princípios do direito natural ${ }^{(10)}$, cujo fim último era a compreensão entre os povos e a realização suprema da paz.

É à luz destas aspirações que se pode perceber a evolução do complexo percurso da diplomacia vaticana na reaproximação das "Europas".

\subsection{A diplomacia de Pio XII na Europa Oriental}

O Vaticano recebeu com preocupação a notícia do acordo de Yalta e consequentemente a extensão da influência de Moscovo ao "coração" da Europa ${ }^{(11)}$. A Igreja russa era considerada um instrumento da política soviética. De igual modo, a restauração da sua presença nos Balcãs e no Médio Oriente era vista como subordinada, antes de mais, ao expansionismo de Moscovo. Os soviéticos, por seu turno, aceitavam uma Igreja à qual não reconheciam, no interior do país, senão o domínio cultual.

Na verdade, Moscovo recusava a Igreja Católica e a sua missão social bem como, e sobretudo, a sua ligação com o Papa de Roma, cuja acção ultrapassava as fronteiras nacionais. O controlo soviético na Polónia e a sua extensão a outros países de Leste (Checoslováquia, Hungria, Eslovénia, Croácia) explicam, num primeiro momento, o desinteresse da diplomacia soviética em estabelecer contactos com a Santa Sé. É que a acção independente da Igreja Católica poderia constituir um elemento perturbador para a URSS. Daí que Moscovo retomasse a ideia de "Terceira Roma", ao assumir-se como o centro da ortodoxia. Por sua vez, a Santa

(10) Pio XII lembrava aos federalistas, aos peregrinos da Pax Christi, aos membros do Colégio da Europa de Bruges as virtudes e a eficácia do processo da construção europeia não sem reivindicar que "o reconhecimento expresso dos direitos de Deus e da sua lei e os princípios do direito natural constituem o fundo sólido sobre o qual são ancorados os direitos do homem", D.C., 1948, col. 1539. Cf. Jean-Pierre Machelon, art. cit., p. 216 e Philippe Chenaux, Une Europe Vaticane? Entre le Plan Marshall et les Traités de Rome, Bruxelles, Éditions Ciaco, 1990, pp. 23-43.

(11) La Civiltà Cattolica, 16 april 1946, pp. 393-399. Cf. Andrea Riccardi, "La diplomatie pontificale en Europe orientale, de la Révolution bolchevique à la coexistance pacifique (1917-1978)", in Le Vatican et la politique européenne, sous la direction de Joël-Benoît d'Onorio, Paris, Éditions Mame, 1994, p. 59 e Philippe Chenaux, ob. cit., p. 23 ss. 
Sé considerava que o sistema socialista intensificava a erradicação do catolicismo na União Soviética e nos países de Leste. Com a guerra fria e com a extensão do domínio socialista a Leste, as medidas de repressão à Igreja e aos católicos acentuaram-se. A Santa Sé não queria, porém, perder algumas relações diplomáticas que a ligavam a certas capitais da Europa de Leste. Significa isto, simples táctica anticomunista ou também estratégia de paz?

Numa perspectiva reconciliadora, a Santa Sé procurou soluções que permitissem constituir um pólo europeu unitário e cristão susceptível de travar a lógica bipolar de um confronto entre os blocos europeus. É neste clima que Pio XII faz uma série de intervenções. Entre outras, saliente-se a carta apostólica Ad Universos Russiae populos ${ }^{(12)}$, de 7 de Junho de 1952, a juntar a textos vários dirigidos aos católicos romenos, polacos, checos, etc.

A verdade, porém, é que uma visão defensiva da Europa, ou seja, da Europa cristã, não colhia já unanimidade no final do pontificado de Pio XII. Daí que alguns membros do alto clero, entre eles, por exemplo, Monsenhor Montini, se mostrassem mais abertos a uma coexistência com o Leste ${ }^{(13)}$. Eles viam, de bom grado, o estreitamento do diálogo com Moscovo (1956). E o certo é que, a partir da segunda metade dos anos cinquenta, o Vaticano recebeu uma série de indicações positivas dos países de Leste que levavam a crer que os soviéticos tinham interesse em estabelecer relações diplomáticas com a Santa Sé. Após a morte de Estaline, em 1953, apesar dessas tímidas aberturas soviéticas, Pio XII toma, no entanto, uma posição mais firme face à invasão da Hungria em 1956.

(12) "Ad Universos Russiae populos" (7-6-1952), in Discorsi e radio messagi di Sua Santità Pio XII, t. XIV, Roma, Cité du Vatican, 1960, pp. 495-502. Veja-se R. P. Robert A. Graham, "Pie XII et le communisme", in Pie XII et la Cité. Actes du Colloque de la Faculté de Droit d'Aix-en-Provence, s.l., Tequi, s.d., pp. 295-317 e Jean Chélini, L'Église sous Pie XII. L'après guerre 1945-1958, Paris, Fayard, 1989, pp. 447-464.

(13) Esta atitude é coincidente com o momento em que Giorgio La Pira procura renovar o diálogo com Moscovo. Cf. Christine de Montclos-Alix, "Europe chrétienne et géopolitique vaticane", in Religions et Transformations de l'Europe, Strasbourg, Presses Universitaires de Strasbourg, 1993, p. 144. Veja-se Marcel Merle, "Le Saint-Siège dans les relations Est-Ouest", in Le Saint-Siège dans les relations internationales, cit., pp. 101-106. 
É particularmente significativo que, na esfera da diplomacia soviética, se reconsidere então a importância das relações dos países de Leste com o Vaticano e a sua tradução particular na recuperação da imagem internacional da URSS. O governo soviético não parecia, no entanto, disposto a pagar o preço exigido pelo Vaticano, isto é, a redefinição com a Santa Sé das condições do estatuto dos católicos na União Soviética e o restabelecimento da liberdade religiosa. Entre 1958 e 1964, apesar da mudança da posição internacional da Igreja ortodoxa russa, que restabelece novas relações com Constantinopla, com vista a integrar o Conselho Ecuménico das Igrejas, a situação dos católicos continuava a ser crítica.

O tema da Europa cristã, no contexto bipolar da guerra fria, seria ditado pelo único móbil de opor uma estrutura válida à irrupção do expansionismo soviético? Ou fazia parte de um projecto mais vasto que visava promover a formação de uma verdadeira comunidade internacional conforme aos princípios da moral cristã?

Pio XII começou por revelar um europeísmo como aspiração a uma ordem superior, em nome do "bem comum", e como regresso à unidade espiritual dos povos europeus. Porém, as últimas reflexões do Papa (a partir de 1952) sobre a Europa adquirem um conteúdo institucional, embora tangível ao espírito tradicional da Igreja - o da união dos povos. Assim, as duas posições, primeiro defensiva, - da civilização cristã ocidental-, depois construtiva e unitária do futuro continental, revelam que a Santa Sé, com Pio XII, tem uma visão europocêntrica, mas não divorciada da independência da Igreja e da sua missão universal. O que permite acentuar que no pensamento de Pio XII coexistem as preocupações específicas com a Europa e uma visão universalista, de cariz evangélico, da função da Igreja Católica.

\section{João XXIII - A Paz entre as Nações e o "Bem Comum Europeu"}

Numa época em que a Europa continuava a debater-se entre a inquietude e a esperança, João XXIII assume o pontificado, exactamente em Outubro de 1958. Uma das suas primeiras iniciativas, que redefiniria o papel da Igreja e uma atitude nova face ao mundo, foi a preparação do Concílio Vaticano II. Se tivermos presente o conjunto da sua obra (doutrinária, pastoral, institucional, de relações internacionais) poder-se-á afirmar que João XXIII tinha uma visão essencialmente ecuménica. 
Comprova-a a sua Encíclica Pacem in terris (1963). No entanto, a Europa esteve também no centro das suas preocupações. A título de exemplo, evoque-se a alocução que ele dirigiu em 12 de Abril de 1960 à Comissão de Saúde Pública da União da Europa Ocidental (UEO). Neste texto, o Papa invoca explicitamente, para além dos elos de ordem política e económica entre as nações europeias, a relevante importância dos laços de ordem humanitária, meio privilegiado para sustentar uma paz durável entre os homens.

Em Junho de 1962, em Estrasburgo, João XXIII referiu-se à importância da Comunidade Europeia do Carvão e do Aço (CECA) e à Comunidade Económica Europeia (CEE), mas lembrou particularmente a existência de um "bem comum europeu". Deste modo, pode afirmar-se que "este bem comum europeu" constituiu uma matriz essencial do seu pensamento. O conceito de "bem comum europeu" radicava no somatório de elementos de vária natureza: económicos, uma prosperidade a desenvolver harmoniosamente; sociais, um equilíbrio a manter; políticos, uma ordem jurídica a estabelecer e a defender. É significativo o facto de João XXIII ${ }^{(14)}$ alicerçar a essência desse "bem comum" nos valores espirituais. É que, a seu ver, existe um património da Europa, um património humanista e universalista, cujos elementos são parte integrante de cada cultura nacional e que são, por si mesmos, elementos de paz e de fraternidade. Do que acaba de se afirmar decorre que a tripla conjugação do humanismo grego, do sistema jurídico romano e do espírito do cristianismo constitui a essência do património europeu, isto é, da sua riqueza intelectual, moral, artística, cultural e até mesmo do progresso técnico e científico. O pontífice reconhecia, assim, que a construção da Europa não era apenas apanágio dos governos, mas era também, e sobretudo, obra dos povos.

\subsection{O pontificado de João XXIII e o diálogo Roma - Moscovo}

Pode perguntar-se se para João XXIII as relações do Vaticano com o mundo soviético assumiam também particular importância como etapa

(14) João XXIII, Mater et Magistra (1961), n. 78-168 e Pacem in Terris (1963), n. 53-58, in Caminhos da Justiça e da Paz. Doutrina Social da Igreja: Documentos de 1891 a 1991, $3^{\text {a }}$ ed., Lisboa, Rei dos Livros, 1993, pp. 161 e 209-210. 
relevante dos ideais ecuménicos. Com efeito, o seu pontificado marcou uma nova fase das relações entre o Vaticano e a União Soviética, ao tempo de Khrouchtchev. O pontífice incentivou uma política de intervenções a favor da paz no mundo e expressou também a sua preocupação relativamente às Igrejas católicas de Leste. Era necessário, em seu entender, retomar o contacto com os bispos desses países e tentar por todas as vias o restabelecimento da liberdade religiosa. O Concílio Vaticano II aparecia então como uma ocasião única ${ }^{(15)}$, ainda que durante os trabalhos preparatórios e os debates conciliares alguns bispos hajam solicitado que o comunismo fosse solenemente condenado. João XXIII considerava todavia que era necessário estimular um diálogo com Moscovo a fim de melhorar a situação do catolicismo no Leste, contribuir para as boas relações internacionais e para a paz e favorecer a ligação com o Patriarcado de Moscovo.

Mas a unidade do continente europeu não era um fim em si mesmo. Daí que a construção comunitária fosse entendida sob o signo da solidariedade entre os povos. Mais concretamente, em 26 de Janeiro de 1961, ao receber os delegados do Parlamento Europeu e dos Estados de África e de Madagáscar associados à Comunidade Económica Europeia, João XXIII defendeu a ajuda dos países mais ricos aos menos favorecidos, invocando a fraternidade efectiva na comunidade dos povos. Como claramente acentua na Encíclica Pacem in terris, a partilha do "bem comum europeu" é "o caminho mais seguro para a união e para a paz entre os homens e, primeiramente, entre os Europeus". É um facto que o Papa não se contentou em aprovar teoricamente o esforço de unificação da Europa. Não deixa de ser importante notar que, sob o seu pontificado, a Santa Sé tenha estabelecido um laço orgânico com as instituições europeias. Foi o que aconteceu com o Conselho da Europa, tornando-se a Santa Sé em 12 de Dezembro de 1962 membro de pleno direito e com

(15) Na primeira sessão do Concílio estavam presentes 35 bispos ( 2 polacos, 2 húngaros, 2 checos, 1 lituano e 1 búlgaro).

${ }^{(16)}$ Os seus representantes fazem parte das três comissões: Comissão do Ensino Superior e de Investigação, Comissão da Educação Extraescolar e do Desenvolvimento Cultural e Comissão do Ensino Geral e Técnico. Cf. Pierre Pflimlin, "Jean XXIII et l'Europe", in Jean XXIII et l'ordre du monde. Actes du Colloque 1988 de la Faculté de Droit d'Aix, sous la direction de Jean Chélini, Paris, Nouvelle Cité, 1989, pp. 139-140. 
carácter permanente do Conselho para a Cooperação Cultural (CCC) do Conselho da Europa ${ }^{(16)}$. A sua missão permanente era também extensiva ao Parlamento Europeu. Por tudo isto, pode deduzir-se que João XXIII (que morre em 3 de Junho de 1963) procurou consolidar uma mensagem europeísta e ecuménica ${ }^{(17)}$.

\section{A missão universal da Europa na perspectiva de Paulo VI}

Paulo VI, eleito em 21 de Junho de 1963, prosseguiu os contactos iniciados pelo seu predecessor. Lembre-se o discurso pronunciado na ONU (4 de Outubro de 1965) em que traçou as linhas da nova acção diplomática da Santa Sé, uma diplomacia não alinhada, mas assente na via do ecumenismo. Não admira, assim, que os encontros bilaterais das igrejas católica e russa se tenham intensificado, contribuindo também, de forma indirecta mas eficaz, para a dinamização das relações com o poder soviético. É ainda a partir dos sucessivos encontros entre Gromyko e o Papa Paulo VI $(1966,1970,1974,1975)$ que as autoridades governamentais soviéticas, sobretudo a partir de 1974, deram expressão a uma atitude de maior abertura às posições do Vaticano.

Sabe-se que a actividade diplomática vaticana em relação ao Leste não colhia apoio unânime no mundo católico. Porém, essa abertura era fruto da tomada de consciência da busca de uma comunhão cordial entre os povos. Segundo o Cardeal Agostino Casaroli, responsável pelas relações externas da Santa Sé e dinamizador de uma intensa actividade nos países de Leste, "o primeiro dever fundamental era salvaguardar e promover vigorosamente a causa da Igreja, a liberdade religiosa e os direitos dos crentes"(18). Procurava-se não tanto um modus vivendi mas sobretudo um modus non moriendi da Igreja Católica ${ }^{(19)}$.

Os soviéticos, por seu turno, persistiam na convicção que os problemas religiosos constituíam assuntos de ordem interna. E se a União Soviética

(17) Idem, ibidem, p. 140.

${ }^{(18)}$ A. Casaroli, "La Santa Sede e de la communità internazionale", conférence du 10 décembre 1974, in Nella Chiesa per il mondo, Milan, Rusconi Libri, 1987, pp. 329-352.

(19) A. Wenger, Le Cardinal Villot (1905-1979), Paris, 1979, p. 175. Cf. Andrea Riccardi, art. cit., in ob. cit., p. 78. 
procurava definir as relações diplomáticas com a Santa Sé na base dos interesses e dos representantes do ecumenismo e das tentativas para credibilizarem a sua política de coexistência pacífica, como se revelou actuante, por sua vez, a diplomacia do Vaticano?

\subsection{O Vaticano e a Conferência de Helsínquia}

É nesta conjuntura que a ideia de uma Conferência Europeia para a Segurança e Cooperação, apresentada ao Vaticano pelo embaixador da Hungria, em 1969, incentivada, como é consabido, pelo Pacto de Varsóvia, surgia como uma outra possibilidade de "encontro" da Igreja Católica e dos governos de Leste. A verdade, porém, é que a participação do Vaticano na Conferência de Helsínquia (1975) tornou-se uma opção difícil, tanto mais que não reunia a unanimidade dos dirigentes católicos romanos. Apesar disso, uma forte pressão foi exercida no sentido de garantir a presença do Vaticano em Helsínquia. OConselho dos assuntos externos da Santa Sé, também designado Secção das Relações com os Estados, através do seu responsável, Cardeal Casaroli, insistia na participação vaticana na Conferência: por um lado, como forma de consolidar as relações entre a Santa Sé e os governos socialistas, por outro lado, como meio propício para recolocar a questão da liberdade religiosa e, acrescente-se ainda uma outra razão, porque a conferência europeia era ocasião oportuna para definir, na Europa dividida, uma linguagem e um conjunto de interesses político-diplomáticos comuns.

É oportuno recordar, no entanto, as críticas dos opositores da Europa de Leste, que viam na Conferência de Helsínquia o reconhecimento de facto das fronteiras de uma Europa dividida em blocos. Mas convém também acentuar que a Conferência de Helsínquia aparecia a outros olhares como o reconhecimento de uma dimensão europeia para além da lógica da divisão. É este, por exemplo, o argumento do Cardeal Agostinho Casaroli, quando define "a Conferência de Helsínquia como o primeiro evento político paneuropeu" (20) e "o maior esforço colectivo dado pelo conjunto dos Estados europeus no domínio da paz". Compreende-se

(20) A. Casaroli, art. cit., in ob. cit., p. 361 e Giovanni Rulli s.j., "Le Saint-Siège et la sécurité en Europe (1972-1994)", in Le Vatican et la politique européenne, cit., pp. 107-113. 
desta forma que a Santa Sé se mostrasse disponível para participar na preparação da Conferência para a Segurança e Cooperação da Europa (CSCE) como representante oficial e não como simples observador. É que as suas finalidades afiguravam-se-lhe convincentes, ou seja, era imperioso reforçar a paz e a segurança na Europa; preservar o continente europeu de novos conflitos; abrir a via de uma mais ampla e pacífica colaboração entre os povos europeus. Em nome da "união dos povos", em nome de uma "Europa como bastião da paz", a Santa Sé sustentava a sua participação com o carácter universal, moral e religioso da sua própria missão.

A actuação da Santa Sé não foi, no entanto, pacífica, tendo suscitado mesmo críticas no mundo católico. No próprio Vaticano reinava alguma perplexidade. O Acto final de Helsínquia (1975) permitia conferir ao bloco socialista uma nova legitimidade. Também é verdade que o Vaticano estava consciente de que esse "espírito de Helsínquia" iria ali encontrar sérios obstáculos na sua aplicação nos países socialistas ${ }^{(21)}$. Mas, afinal, o Acto de Helsínquia dava cobertura à defesa dos direitos do homem (e da Igreja) no mundo de influência soviética. Neste quadro, não há dúvida que, com Paulo VI, se assistiu a uma evolução na dinâmica das orientações da Santa Sé face à unidade europeia. Com isto, pretende-se dizer que as suas concepções não desejavam demarcar-se das posições ocidentais, mas orientavam-se ainda, e doravante, no sentido da defesa das liberdades da Europa de Leste. No fundo, a salvaguarda da liberdade religiosa dava expressão ao enaltecimento da paz, da coexistência entre as nações e, consequentemente, à reaproximação das "Europas"(22).

(21) Veja-se A. Garrascosa Coso, La Santa Sede y la conferencia sobre la Seguridad y la Cooperacion en Europa, Caja de Ahorros de Cuenca y Ciudad Real, 1990; Christine de Montclos-Alix, "Le Saint-Siège et l'Europe", in Le Saint-Siège dans les relations internationales, Paris, Cerf/Cujas, 1989, pp. 137-161 e leia-se também V. H. Ghebali, La Diplomatie de la détente: la CSCE 1973-1989, Bruxelles, 1989. Cf. Marie Thérèse Bitsch, Histoire de la construction européenne, Bruxelles, Éditions Complexe, 1996, p. 203.

(22) Por exemplo, o Cardeal Casaroli na conferência que pronunciou sobre "Le Saint-Siège et les problèmes actuels de l'Europe", na Universidade de Linz, em Novembro de 1977, afirmava que "la paix et la bonne harmonie en Europe sont tellement importantes, non seulement pour ce continent mais pour le monde entier, que le Saint-Siège ne peut manquer de faire le plus grand cas de tout ce qui les concerne" (D.C., n. ${ }^{\circ} 1740,1978$, p. 369). Leia-se ainda a "Intervention de Casaroli à la Conférence d'Helsinki à la séance plénière du 6 juillet 1973", D.C., 1973, p. 723. 
Recorde-se, porém, que, para além do aspecto religioso, existia igualmente um projecto político. E é neste horizonte que o Acto final de Helsínquia e o seu decálogo se revestem de uma capital importância para a segurança da Europa, na medida em que são vistos como forma de cristalização dos conflitos mundiais, como enunciado de valores comuns, como código de conduta comum. Eles ditam a abstenção do recurso à força, sublinham o reconhecimento da inviolabilidade das fronteiras, reiteram a exigência do respeito pela integridade territorial dos Estados, em suma, afirmam, a inevitabilidade da aceitação do equilíbrio europeu.

Ora, é no contexto destas aspirações comuns que melhor se entende a missão pacificadora de Paulo VI (1963-1978), o pontífice que prosseguiu os trabalhos do Concílio Vaticano II, que estimulou a colegialidade episcopal, que aprofundou o diálogo Este-Oeste. Durante o seu pontificado, o Papa apoia e encoraja a construção da Europa no sentido de uma unidade mais profunda, mais sólida, mais orgânica, justificando-a como percurso essencial no caminho progressivo da fraternidade entre os povos. Mas que Europa? É que a Europa, a seu ver, encarnadora de uma missão universal, não é só, ou melhor, não pode ser, tão-só, a "pequena Europa" ocidental. Ela é também, aos olhos do Vaticano e nas aspirações universalistas de Paulo VI, essa outra Europa, a oriental, também ela com seculares raízes cristãs ${ }^{(23)}$.

\section{A unidade espiritual da Europa na visão de João Paulo II}

João Paulo II, eleito em 16 de Outubro de 1978, homem de Leste, eslavo, polaco de nacionalidade, natural de Cracóvia - cidade em que os intelectuais sempre combateram o comunismo, (lembre-se o grupo ZNAK), conhecedor da realidade socialista, logo a 19 de Dezembro de 1978 incentivava o Conselho das Conferências Episcopais da Europa

(23) Andrea Riccardi, "La diplomatie pontificale en Europe orientale, de la Révolution bolchevique à la coexistence pacifique (1917-1978)", in Le Vatican et la politique européenne, sous la direction de Joël-Benoît d'Onorio, Paris, Éditions Mame, 1994, pp. 72-84; Christine de Montclos-Alix, "Le Saint-Siège et l'Europe", in Le Saint-Siège et les relations internationales, cit., pp. 143-154; Histoire de la papauté. 2000 ans de mission et de tribulations, sous la direction de Yves-Marie Hilaire, Paris, Éditions Tallandier, 1996, pp. 469-480. 
(CCEE) a revivificar "a alma cristã da Europa na qual radica a sua unidade"(24). Esta ideia persistirá no seu pensamento e assume-se como uma matriz essencial do seu discurso ${ }^{(25)}$. É a esta luz que a visão europeia de João Paulo II se afirma como não tributária nem de sistemas políticos nem de sistemas ideológicos, nem pretende confinar-se aos limites da Comunidade ou da União Europeia. Explica-se, assim, como para este pontífice ele representa e abarca a totalidade do continente, retomando, o Papa, desta forma, a conhecida expressão de De Gaulle: "a Europa, do Atlântico aos Urais"(26).

João Paulo II reforçou esta tese na alocução pronunciada em 5 de Abril de 1979, ao sustentar expressamente que os doze estados da Comunidade Económica Europeia (CEE) não constituíam, só eles, toda a Europa ${ }^{(27)}$. Não surpreende que, em 1985, volte a sublinhar que os "europeus não poderiam resignar-se à divisão do seu continente", defendendo, em alternativa, a integração no património europeu de todos os países que, por razões várias e diferentes, não participavam ainda na unidade comunitária. A objectivação concreta de um espírito formado pela tradição cristã exigia, a seus olhos, a abertura aos outros, o respeito fraternal, o desenvolvimento do sentido do universal ${ }^{(28)}$, atitude que volta a acentuar perante o Conselho da Europa, em 1988.

(24) “Discours du 19 décembre 1978 au Conseil des Conférences Épiscopales d'Europe", D.C., n. ${ }^{\circ} 1755,1979$, p. 17.

(25) "Il est nécessaire de donner une âme à l'Europe d'aujourd'hui", (Lettre du 2 janvier 1986 aux présidents des Conférences Épiscopales d'Europe, D.C., n. '1912, 1986, p. 184) e "L'Europe [est] appellée à retrouver son âme..." (Discours du 21 avril 1986 au colloque de l'Institut polonais de culture chrétienne et du Conseil pontifical de la Culture, D.C., n. ${ }^{\circ} 1919,1986$, p. 534); "[...] aider sa patrie européenne à redécouvrir son âme chrétienne..." (Homélie du 4 mai 1987 à la Cathédrale de Spire, D.C., n. ${ }^{\circ} 1941,1987$, p. 591); " [...] l'Europe... à la recherche de son âme..." (Discours du 11 octobre 1988 à Strasbourg devant l'Assemblée des Communautés européennes, D. C., n. ${ }^{\circ} 1971,1988$, p. 1044).

(26) Discours des $1^{\text {er }}$ juin 1980 à l'UNESCO, 5 octobre 1982 au Ve Symposium du Conseil des Conférences Épiscopales d'Europe, 10 septembre 1983, homélie du 4 mai 1987 à Spire, discours du 22 décembre 1989 aux Cardinaux et à la Curie romaine, Discours du 9 juin 1991 à Conférence des évêques de Pologne, etc...

(27) "Discours du 5 avril 1979", D.C., n. ${ }^{\circ} 1763,1979$, p. 432.

(28) Leia-se o "Discours du 20 mai 1985 dans la Commission de Bruxelles", D.C., n. ${ }^{\circ} 1899,1985$, p. 696. 
Ora, esta posição vinha confirmar o princípio da subsidariedade que, implícita ou explicitamente, é evocado. João Paulo II fundamentava o seu ideal de construção da Europa, por um lado, nas tradições próprias de cada país e de cada região e, por outro lado, nas necessidades reais de cada um dos membros da comunidade. Com esta tese, pode dizer-se, que ele se demarcava das concepções que postulavam a construção de uma estrutura europeia unicitária e abstracta. É que, ao preservarem-se no respeito recíproco os justos direitos de cada nação, não se esqueciam, isto é, não se deveriam esquecer os direitos fundamentais do homem ${ }^{(29)}$.

No que concerne à arquitectura da prática europeia, encontramos em alguns passos dos seus textos, com frequência, a explicitação da ideia de que a organização comunitária não pode fazer tábua rasa da história da Europa. Isto significa, por um lado, que as nações são elemento determinante e factor permanente de identidade e, por outro lado, que não pode instaurar-se uma nova Europa em detrimento dos legítimos interesses dos povos, e traduz ainda que os corpos intermediários, isto é, as instituições comunitárias serão sempre instrumentos importantes, mas, só por si, não constituem a manifestação real da Europa. Em suma, são os homens que a fazem. Por conseguinte, a vida das nações e dos indivíduos aparece-lhe como uma exigência na realização do processo de construção europeia. E é ainda à luz desta reflexão que ganham sentido as suas palavras proferidas em 1987 para assinalar o $30^{e}$ aniversário do Tratado de Roma em que defende a necessidade de salvaguardar, sem um nivelamento redutor e empobrecedor, o passado, as mentalidades, as culturas, as possibilidades reais do continente europeu.

Dentro da linha de abordagem anteriormente seguida, julgamos não ser difícil perceber que a noção de Europa de João Paulo II é uma noção abrangente, o mesmo é dizer, é a defesa de uma Europa alargada que recobre a totalidade de um continente. De facto, em Janeiro de 1991, o pontífice afirma, em jeito de lamento, que "nada era mais prejudicial ao equilíbrio da Europa, ou seja, à manutenção da paz do continente,

(29) "Discours du 5 avril 1979", D.C., n. ${ }^{\circ} 1763,1979$, p. 432; "Lettre apostolique Egregiae virtutis du 31 décembre 1980, pour la proclamation des saints Cyrille et Méthode comme co-patrons de l'Europe", D.C., n. ${ }^{\circ} 1801,1981$, p. 111 e "Message du 26 août 1989 à la Conférence des évêques de Pologne pour le $50^{\circ}$ anniversaire du début de la Seconde Guerre Mondiale", D.C., n. ${ }^{\circ} 1991,1989$, p. 824. 
do que uma nova dualidade: "a Europa dos ricos e a Europa dos pobres, a das regiões modernas e a das regiões economicamente atrasadas"(30). Assim se entende que, aos seus olhos, a Europa do Ocidente tenha uma "dívida de justiça" em relação aos países do bloco de Leste. A esse nível, como desenvolve também na encíclica Centesimus Annus, a Comunidade Europeia deveria visar, em última instância, um "desenvolvimento solidário"(31), que não esquecesse, todavia, a solidariedade com os demais países extra-europeus (concretamente com o Terceiro Mundo, em particular, no quadro da convenção de Lomé). Tal desiderato pressupunha uma necessária dimensão económica, que João Paulo II não deixa de invocar, mas, acentua, sempre "sobredeterminada por uma função social intrinsecamente moral"(32).

\subsection{A "refundação da cultura europeia" e a unidade espiritual}

De tudo o que acaba de se explicitar, pode concluir-se que o pensamento do Papa actual reflecte uma concepção de unidade da Europa cujo cerne reside essencialmente na cultura. Isto é, o critério de construção europeia para João Paulo II é, na essência, cultural. Como afirmou no discurso de 31 de Outubro de 1991, num Simpósio Présinodal, "rico mosaico de linhas harmoniosas, a Europa cultural é anterior à Europa política e económica, embora seja esta a que retém as atenções actualmente".

Por outro lado, em seu juízo, para além das legítimas características nacionais, a cultura europeia tem uma matriz comum, o cristianismo. A este propósito, reiterou que é a própria história que revela uma Europa impregnada da fé cristã. É ainda na lógica desta argumentação que a noção de respeito pela pessoa humana emerge como a pedra angular sobre a qual edifica, em boa parte, a sua tese sobre a construção europeia. $\mathrm{O}$ mesmo é dizer que o primado da pessoa humana deveria ser um

(30) "Discours du 12 janvier 1991 au corps diplomatique accredité près le Saint-Siège", D.C., n. ${ }^{\circ}$ 2022, 1991, p. 193.

(31) "Discours du 7 décembre 1990", citado por Jean-Maris Guénois, "Maastricht vu du Vatican", Le Temps de l'Église, n. ${ }^{\circ} 1$, septembre 1992, p. 10.

(32) "Discours du 3 décembre 1990 aux présidents des confédérations industrielles européennes", citado por Jean-Maris Guénois, art. cit., p. 10. 
aspecto nodal da civilização europeia. Consequentemente, a marcha para uma nova unidade da Europa não poderia deixar de levar em conta, de forma incontornável, a herança cristã ${ }^{(33)}$.

Atendendo a esta concepção de unidade da Europa de João Paulo II, fácil se torna detectar em alguns passos dos seus discursos um evidente conhecimento do crescente movimento de secularização, do indiferentismo religioso e do ateísmo, que designou como "fortes correntes da contra-evangelização". É com base neste pressuposto e em oposição a essa "crise ética" do europeu, isto é, à crise dos valores morais, e à negação da dimensão religiosa da pessoa humana (lembre-se a influência da filosofia das Luzes) que o Papa enuncia os valores e os direitos fundamentais cristãos: liberdade, justiça, solidariedade, responsabilidade moral - cadinho de um "bem comum", o mesmo é dizer, a enriquecedora herança cultural e religiosa ${ }^{(34)}$. Em alternativa àquele "modelo antropológico e cultural" que, como afirma, "conduz o homem ao cepticismo, ao relativismo, ao niilismo, à angústia existencial", João Paulo II propõe a urgente "refundação da cultura europeia como empresa decisiva e urgente" ${ }^{\prime(35)}$, já que, na sua óptica, o diálogo com o Evangelho é fecundo e constitui parte integrante desta cultura ${ }^{(36)}$. Em sua opinião, é impensável uma Europa sem uma dimensão transcendente ${ }^{(37)}$. Um pressuposto deste

(33) "Discours du 21 avril 1990 à Prague", D.C., n. ${ }^{\circ}$ 2007, 1990, p. 548.

${ }^{(34)}$ Entre outros textos leiam-se, por exemplo, o "Discours du 11 octobre 1985 au VI ${ }^{e}$ Symposium du Conseil des Conférences Épiscopales d'Europe", D.C., n. ${ }^{\circ} 1906,1985$, p. 1085 e "Discours du 20 mai 1985 au siège de la CEE à Bruxelles", D.C., n. ${ }^{\circ} 1899,1985$, p. 695.

(35) “Homélie du 11 mai 1986 à Ravenne", D.C., n. ${ }^{\circ} 1921,1986$, p. 636.

(36) "Discours du 31 octobre 1991 au symposium présynodal sur l'Europe", D.C., n. ${ }^{\circ}$ 2040, 1991, p. 1069.

(37) Para o Papa, com efeito, "não pode existir a comunidade humana verdadeira sem esses valores culturais e espirituais pelos quais o homem se torna verdadeiramente homem" ("Allocution du 11 mai 1986 à Ravenne", D.C., n. ${ }^{\circ} 1921,1986$, p. 636). Ou ainda: "a Europa tem necessidade de Cristo e do Evangelho porque é neles que se encontram as raízes de todos os povos" (Discours du 6 novembre 1981 au colloque sur "Les Racines Chrétiennes des Nations Européennes", D.C., n. ${ }^{\circ} 1819,1981$, p. 1056. Há, todavia, três textos marcantes em que João Paulo II reivindica a necessária mediação espiritual, a imprescindível reespiritualização e reevangelização da Europa para vencer os efeitos éticos e sociais das "fortes correntes de contra-evangelização" (seculari- 
tipo fundamenta-se na convicção de que a ausência dos valores cristãos fragilizaria a organização da Europa ${ }^{(38)}$.

Estas ideias tiveram expressão quando, ao relembrar os princípios do Concílio Vaticano II (e da constituição pastoral Gaudium et spes) sobre o lugar da Igreja no mundo contemporâneo, João Paulo II definiu a função particular da doutrina social da Igreja católica como um conjunto de princípios indispensáveis à construção de um sistema social e económico mais justo ${ }^{(39)}$. Ao mesmo tempo, confere-lhe o estatuto de elemento de mediação evangelizadora na comunidade política.

Assim sendo, cabe à Igreja Católica reencontrar um espaço religioso no seio das culturas, dado que o património cristão é agente e criador de cultura ${ }^{(40)}$. E é a partir desta conclusão que se pode compreender o entendimento de João Paulo II do projecto de nova evangelização, movido e estimulado pela ideal insistente de que "a velha Europa cristã cresça cada vez mais"(41). À luz dos acontecimentos que ocorriam na Europa, João Paulo II anunciava a necessidade de "reflectir mais intensamente a importância desta hora histórica para a Europa e para a Igreja"(42).

Como proceder? Pela reevangelização. Que nova evangelização? E para que Europa?

zação, ateísmo, indiferentismo). São eles: a sua homilia de 4 de Maio de 1987 junto da Catedral de Spire (D.C., n. ${ }^{\circ} 1941,1987$, p. 589; o discurso à Assembleia europeia de Estrasburgo de 11 de Outubro de 1988 (D.C., n. ${ }^{\circ} 1971,1988$, p. 1044) e a sua alocução de 5 de Junho de 1990 à reunião preparatória ao Sínodo dos bispos da Europa (D.C., n. ${ }^{\circ}$ 2010, 1990, p. 686).

(38) "Discours du 3 décembre 1990 aux présidents des confédérations industrielles européennes", citado por Jean-Maris Guénois, "Maastricht vu du Vatican", art. cit., p. 10.

(39) "Discours de 12 janvier 1993 au deuxième groupe d'évêques polonais en visite ad limina", ORLF, du 16 février 1993, p. 10.

(40) "Discours du 21 avril 1986 à un congrès culturel européen", D.C., n. ${ }^{\circ} 1919$, 1986, p. 533.

(41) "Homélie du 28 novembre 1991 à la messe d'ouverture du Synode spécial des évêques d'Europe", D.C., n. ${ }^{\circ}$ 2041, 1992, p. 13.

(42) Idem, ibidem, p. 19. 


\section{A reenvangelização no seio da "Europa secularizada"}

A construção europeia suscitou a criação de diversos organismos responsáveis pela coordenação da acção das Igrejas à escala da Europa. Eles testemunham o esforço desenvolvido pelas Igrejas (cristãs e não cristãs) para garantirem uma representação junto das instituições europeias e para desenvolver uma consciência eclesial.

\subsection{Colegialidade episcopal e reevangelização da Europa}

Ora, se essas instâncias colaboram regularmente entre si, como é o caso da Conferência das Igrejas Europeias, fundada em 1959, e o Conselho das Conferências Episcopais da Europa (CCEE), criado oficialmente em 1971, a verdade é que, por vezes, as reacções negativas são também manifestas. Assim, os encontros destes organismos (Trento, Erfurt, Santiago de Compostela) saldaram-se, por um lado, num diálogo positivo e amplo, mas, por outro lado, fizeram ressaltar as diferenças de eclesiologia entre as Igrejas ${ }^{(43)}$.

Para o que nos interessa ora analisar, é particularmente significativa a criação do Conselho das Conferências Episcopais da Europa (CCEE), que reuniu pela primeira vez ao tempo de Paulo VI, em 25 de Março de $1979^{(44)}$. No período pós-Vaticano II, cumpria-se, desta forma, o desejo formulado por este pontífice, referido também em alguns textos conciliares (editados em 1966), sobre a necessidade de cooperação dos bispos por forma a promover e assegurar o "bem comum". Assim, esta colegialidade é defendida como um instrumento privilegiado para a execução do projecto pontifício de "reevangelização da Europa". Como se vê, paralelamente à reestruturação da Comunidade Europeia, a hierarquia da Igreja Católica sentiu novas exigências pastorais ${ }^{(45)}$. De facto, Paulo VI,

${ }^{(43)}$ Marc Lenders, "La Commission œcuménique européenne", in Religions et Transformations de l'Europe, cit., pp. 293-307.

${ }^{(44)}$ Criado em 1971, depois de vários anos de existência de um simples secretariado, os seus Estatutos foram aprovados canonicamente em 10 de Janeiro de 1977.

(45) Jean Chélini et Blandine, L'Église de Jean Paul II face à l'Europe. Dix années d'action (1978-1988), Paris, Nouvelle Cité, 1989, pp. 123-125 e La Religion, fait privé et réalité publique. La place de l'Église dans les Sociétés pluralistes, Paris, Les Éditions du Cerf, 1997, pp. 121-124. 
na alocução ao Simpósio dos Bispos da Europa, reunidos em Roma, em 1975, afirmava que a Europa tem algo de comum, algo que lhe dá alma - a fée ${ }^{(46)}$. E é nesta mesma linha de pensamento que se tem de compreender o discurso de João Paulo II proferido no Simpósio dos Bispos de 5 de Outubro de 1982 em que reforça a ideia primacial de que "a catolicidade é o fundamento da Europa" (47). Com efeito, esta reflexão permanente sobre a missão central da Igreja, a reevangelização, é o tema nodal dos trabalhos do Conselho das Conferências Episcopais da Europa. É neste horizonte que ele se define como centro de reflexão institucionalizada do episcopado católico europeu, que promove o diálogo das conferências episcopais europeias ${ }^{(48)}$, no sentido da colegialidade, fundamentado nos princípios basilares da solidariedade e da subsidiaridade ${ }^{(49)}$.

Numa primeira fase - a fase de formação e de auto-definição durante os anos 70-80 - o Conselho das Conferências Episcopais da Europa define, por um lado, as linhas institucionais e, por outro lado, procura fazer uma adaptação das questões pós-conciliares às exigências específicas do continente europeu. Significa isto que, para os episcopados da Europa, era inevitável repensar o lugar da Igreja na nova Europa, que não se queria apenas económica, mas também "mais humana, mais solidária e mais respeitadora dos valores cristãos"(50). Ora, a mutação de uma perspectiva essencialmente intra-eclesial para uma visão cada vez mais europeia é assumida muito explicitamente na Déclaration sur l'Europe en 1980. Este documento, cujo tema versa sobre as "Responsabilidades dos cristãos face à Europa de hoje e de amanhã", enuncia os postulados de uma ética social católica, cuja concretude modelaria o continente europeu

\footnotetext{
(46) Leia-se esta alocução, de 18 de Outubro de 1975, D.C., n. ${ }^{\circ} 1685,1975$, p. 902.

(47) "Allocution au Symposium des évêques, 5 octobre 1982", D.C., n. '1942, p. 1153 e leia-se também n. 1961,1988 , p. 440.

${ }^{(48)}$ O conselho da CCEE é constituído por membros e todas as Conferências episcopais da Europa estão representadas por um delegado nomeado por 3 anos. O secretariado permanente tem a sua sede em St. Gallen (Suíça).

(49) Veja-se Ch. Tiede, Bischöfe - Collegial für Europa. Der Rat der Europaïschen bischofskonferenzen im Dienst einer sozial-ethisch Konkretisierten Evangelisierung, Münster, 1991, sobretudo os apêndices finais que contêm os estatutos da CCEE e COMECE.

${ }^{\left({ }^{50}\right)}$ Helmut Steindl, "Le Conseil des Conférences Épiscopales d'Europe (CCEE)”, in Religions et Transformations de l'Europe, cit., pp. 285-291. Leia-se Christine de Montclos-Alix, "Le Saint-Siège et l'Europe", in Le Saint - Siège dans les relations internationales, cit., pp. 154-161.
} 
no sentido de uma redução das tensões entre Leste e Oeste. No fundo, a CCEE sustentava a importância da colaboração colegial, a necessidade do diálogo ecuménico, a urgente tomada de consciência da Europa face a si mesma e a sua responsabilização em relação aos outros povos (sobretudo aos do Terceiro Mundo). Após esta primeira fase de auto-definição, este organismo católico desenvolveu, nos anos 80 , um trabalho de ampla projeç̧ão de que resultaram diversos encontros ecuménicos europeus (Chantilly - 1978, Logumkloster (Dinamarca) - 1981; Riva del Garda 1984; Erfurt - 1988; Santiago de Compostela - 1991).

Fazendo uma retrospectiva das actividades da CCEE, poder-se-á concluir que elas se têm centrado em dois planos essenciais: por um lado, o trabalho em prol da paz e da justiça. A este nível recorde-se, a título de exemplo, a atenção com que o Conselho das Conferências Episcopais seguiu os trabalhos da Conferência sobre a Segurança e a Cooperação na Europa (CSCE); a consulta sobre os "Direitos do Homem - Justiça e Paz", em Setembro de 1981. Num segundo plano, a CCEE desenvolve um intenso labor de acentuado cariz teológico sobre a missão primordial da Igreja - a evangelização. Este imperativo está bem patente nos três simpósios realizados na década de 80 . A saber: em 1982, sobre a evangelização do continente europeu; em 1985, sobre secularização e evangelização e em 1989 sobre os desafios para a evangelização, concretamente os problemas da bioética.

Importa salientar que o Conselho das Conferências Episcopais da Europa visa essencialmente a auto-definição da Igreja Católica na Europa em construção, na base de um projecto que é definido e alicerçado num diálogo entre a fé cristã, a razão científica e a evolução tecnológica e social. E isto sugere que, na sua perspectiva, são estes os elementos fundamentais da cultura europeia ${ }^{(51)}$.

\subsection{As relações entre a Igreja Católica e as instituições europeias - a COMECE}

No quadro da Europa comunitária, o Conselho das Conferências Episcopais da Europa (CCEE), pela sua composição e pelo seu estatuto, revelava-se pouco eficaz na reflexão sobre as questões comunitárias,

(51) Helmut Steindl, art. cit., p. 291. Veja-se também Philippe Laurent, art. cit., pp. 85-94. 
pelo que se tornou necessário criar um novo organismo que congregasse tão-só bispos dos países membros da CEE. É assim que nasce em 3 de Março de 1980, sob o impulso de João Paulo II, a Comissão dos Episcopados da Comunidade Europeia (COMECE), sediada em Bruxelas. É verdade que esta Comissão não tem um estatuto oficial junto da União Europeia. Importa no entanto acentuar a pertinência desta instituição mediadora como instrumento adequado que permite às Conferências Episcopais assumir melhor a sua responsabilidade pastoral face ao processo de integração europeia ${ }^{(52)}$. Concretamente, a COMECE favorece o espírito de colegialidade e estimula uma estreita cooperação entre os episcopados dos países da União Europeia e a Santa Sé. Será dentro destes parâmetros que esta Comissão, formada pelos bispos eleitos por três anos como representantes de cada episcopado dos países da União Europeia, em reunião plenária anual, analisa, informa e debate as questões da Europa comunitária. Questões múltiplas com que se confrontam as Igrejas na Europa: bioética, ética social, migrações, família, pobreza, desemprego, comunicação social, condição feminina, ensino, cultura, armamento, paz, alargamento da União Europeia, união monetária, etc. ${ }^{(53)}$.

É esta multiplicidade de objectivos que justifica a necessária cooperação da COMECE com o Conselho das Conferências Episcopais da Europa (CCEE) e que, por outro lado, torna inevitáveis as relações com outras conferências episcopais, com outros organismos ou personalidades. Tudo parece apontar para um tempo caracterizado por um intercâmbio constante e uma colaboração mais estreita entre as diversas instituições. É o que transparece das declarações do primeiro presidente da COMECE, Cardeal Heugsbach, à agência France-Press, em que se defende a necessidade de integrar rapidamente "todos os países europeus, de constituição democrática, que satisfazem as exigências dos tratados de Roma". Um bom exemplo para ilustrar esta afirmação é o interesse demonstrado pela integração da Grécia, de Portugal e Espanha nas Comunidades Europeias. Também neste espírito, em reunião de 12 de Março de 1982, em Bruxelas, aos delegados habituais dos episcopados da Comunidade se juntaram

${ }^{(52)}$ Sobre os trabalhos da Comunidade Europeia e do Conselho da Europa a COMECE começou a publicar uma revista bitrimestral, a SIPECA, (Service $d^{\prime}$ Information pastorale européenne catholique), $\mathrm{n} .^{\circ} 1$.

${ }^{(53)}$ Jean et Blandine Chélini, L'Église de Jean-Paul II face à l'Europe, cit., pp. 136-137. 
os bispos de Espanha e de Portugal. Convém sublinhar que, a par do acompanhamento próximo dos debates parlamentares, a COMECE examina continuamente, e com particular atenção, as questões múltiplas da política europeia.

Por outro lado, não se deve ignorar a reconhecida importância dos encontros de trabalho, visitas e debates, que têm fomentado o aprofundamento das relações entre a COMECE e as instituições comunitárias ${ }^{(54)}$. É significativo que em 12 de Abril de 1984 tenha sido publicada uma mensagem por ocasião das eleições parlamentares em que se sintetizam as preocupações de João Paulo II e da Igreja Católica em relação à Europa. Faz sentido a pergunta do Presidente da COMECE: “L'Europe pour quoi faire?"(55). Esta interrogação exprime perplexidade, se não mesmo cepticismo, mas uma perplexidade a que não é alheia a esperança de raiz cristã. É que, a seu ver, no seio de uma crise ética, é possível a construção de uma comunidade nova, ao serviço do homem e de uma Europa que ultrapasse largamente as fronteiras da comunidade europeia. Assim sendo, construir esta Europa é missão a cumprir por todos, de modo a dar à comunidade europeia um novo alento, uma alma e uma fé.

Subjacente a essa abertura a um alargamento europeu está a convicção de que numa Europa em que se acolhem novas sensibilidades culturais e espirituais se fomentam os laços de união entre os cristãos, entre igrejas, numa profunda comunhão eclesial, ultrapassando-se, deste modo, os laços de puro cariz económico.

Como já atrás se disse, a COMECE tornava-se necessária para melhor fazer face às questões comuns que se colocavam aos Episcopados da Comunidade Europeia. É verdade que, em Janeiro de 1950, a Santa Sé incentivara já a criação de um Secretariado católico para os problemas europeus, em Estrasburgo; em 1962, sob o pontificado de João XXIII, a Santa Sé tornara-se membro do Conselho para a Cooperação Cultural

(54) Recorde-se, entre outras, a visita da comissão executiva da COMECE, presidida pelo Cardeal Heugsbach à Comissão Europeia em Fevereiro de 1983, em Bruxelas; o encontro com M. Pisani, comissário encarregado das questões do desenvolvimento; em 19-20 de Junho de 1985 o encontro com Jacques Delors no qual informa os bispos da situação e do futuro da comunidade europeia; debates vários com Pierre Pflimlin, Natali, Ripa di Meano tiveram lugar em 1987 e, registe-se ainda, em 1987, o encontro com o Secretário-Geral do Conselho da Europa. Cf. Jean Chélini et Blandine, ob. cit., pp. 139-140.

(55) Veja-se SIPECA, n. ${ }^{\circ}$ 20, mai 1984. 
do Conselho da Europa; em 1969, ela respondera favoravelmente ao apelo dos Estados membros do Pacto de Varsóvia para a organização de uma conferência paneuropeia sobre a segurança e a cooperação na Europa, cujos trabalhos se iniciaram em 1973, em Helsínquia. Para além disso, havia já representantes da Santa Sé, desde 1970, junto das Comunidades Europeias e do Conselho da Europa, com função de observadores permanentes. É ainda o caso da Nunciatura Apostólica que continua a assegurar as relações oficiais, em nome da Santa Sé. Mas é com a COMECE que se cria um organismo interlocutor com a União Europeia.

Mesmo depois das importantes transformações de 1989, a COMECE mantém as suas funções junto da União Europeia, e intervém de forma mais activa no processo de integração dos antigos países comunistas. Realce-se igualmente que um largo espectro de temas debatidos nas instâncias europeias, dadas as suas incidências pastorais, são objecto de reflexão nas reuniões, debates e publicações da $C O M E C E^{(56)}$.

Para além dos seus fins específicos (sensibilizar e informar os bispos e, com eles, as comunidades eclesiais, manifestar a colegialidade entre os episcopados, estimular as reflexões sobre os desafios que a construção europeia coloca ao nível pastoral, e estabelecer contactos regulares com os políticos, os parlamentares e as instituições europeias), a COMECE é ainda interlocutor autorizado junto de outras comissões ecuménicas e, importa repetir, alargou o seu horizonte para os países da Europa de Leste, estimulando a sua inserção na unificação europeia ${ }^{(57)}$. Anote-se ainda que colaborou no seminário com o Patriarcado de Constantinopla, reflectiu, na sua reunião plenária (19-20 de Novembro de 1998) sobre $O$ aprofundamento da democracia na União Europeia e teve a sua representação na Assembleia especial do Sínodo dos Bispos para a Europa, agendada em Setembro-Outubro de $1999^{(58)}$. Em suma, a COMECE tem procurado desenvolver uma intensa actividade de criação de um ponto de encontro entre a vida da Igreja Católica e os responsáveis políticos da União Europeia, diálogo a que o episcopado português não tem ficado alheio.

(56) Entre as publicações refira-se a revista bimestral L'Europe au fils de jours SIPECA (n. $\left.{ }^{\circ} 1,1980\right)$ e a Europe - Infos, publicada a partir de Março de 1995, com periodicidade mensal, incluindo dois números especiais: um, sobre bioética, o outro sobre o tema do desenvolvimento: Lomé, um novo interlocutor.

(57) $L$ 'Europe au fils de jours..., cit., p. 38.

${ }^{(58)}$ Leia-se Noël Treanor, Rapport Annuel 1997 de la COMECE, Bruxelles, 1997. 


\subsection{A intervenção do Episcopado Português}

Espanha e Portugal entraram na Comunidade Europeia em 29 de Março de 1985, oficialmente em 1 de Janeiro de 1986. Em 28 de Março de 1985 teve lugar em Essen a reunião da comissão executiva da COMECE, a qual decidiu, desde logo, dirigir uma carta às conferências episcopais dos países ibéricos. Se é verdade que o alargamento lançava um desafio à Europa e, em particular, aos jovens países membros, também se tornava evidente aos olhos dos responsáveis da COMECE que a Comunidade Europeia poderia beneficiar, através deles, de uma maior abertura aos países em desenvolvimento, concretamente, aos países da América Latina.

Recorde-se que desde a fundação do Conselho das Conferências Episcopais da Europa (CCEE) a Conferência Episcopal Portuguesa esteve sempre representada, pese embora o seu estatuto de observador e não $o$ de membro de pleno direito. De forma sucinta, pode dizer-se que $D$. Manuel de Almeida Trindade, Bispo de Aveiro e Presidente da Conferência Episcopal Portuguesa, exprime o regozijo do Episcopado Português pela adesão de Portugal à CEE, que reforça assim "a sua integração no meio geográfico e espiritual que é a Europa"(59). E se essa integração constituía um desafio para a Igreja em Portugal, o certo é que interessava também à Igreja dos demais países comunitários. Esta concepção está patente $\mathrm{e}$ ganha significado na Nota Pastoral emanada do Patriarcado de Lisboa em 24 de Junho de 1985. O Cardeal Patriarca, D. António Ribeiro, ao invocar a condicionalidade histórica geral e a aplicação do princípio de solidariedade, particulariza o peso do contributo português, representado pelo relevante fundo cultural e "experiência histórica de longa convivência com os outros países, designadamente da África e da América Latina" ${ }^{\prime(60)}$. Na mesma linha, após a assinatura do protocolo da entrada de Portugal na CEE, em 10 de Junho de 1985, a Conferência Episcopal Portuguesa publicou igualmente uma Nota Pastoral que decorre

${ }^{(59)}$ Leia-se a "Nota Pastoral do Conselho Permanente sobre a Integração de Portugal na Comunidade Económica Europeia", in Conferência Episcopal Portuguesa. Documentos Pastorais, vol. III, 1983-1990, Lisboa, Rei dos Livros, 1991, pp. 357-360. Foi também publicado na D.C., n. ${ }^{\circ} 1908,1985$, pp. 1176-1881.

${ }^{(60)}$ Idem, ibidem, p. 358. 
da reflexão efectuada no Patriarcado de Lisboa com uma considerável participação de leigos ${ }^{(61)}$.

A Igreja portuguesa tinha, deste modo, também uma palavra a dizer. A análise das suas posições permite-nos concluir que ganham particular relevância os argumentos e as ilações de teor social, ético e da esfera espiritual. Na verdade, o reconhecimento do significado cristão da unidade da Europa é mediatizado pela necessidade de encarar a adesão portuguesa como ocasião privilegiada para realizar e aprofundar os valores próprios da comunidade nacional portuguesa e das comunidades regionais e locais. Essa ideia de uma Europa cristã reforça-se na concepção de um projecto de desenvolvimento capaz de defender e promover os direitos do homem e os valores humanos fundamentais. Como assinala o Cardeal Patriarca, D. António Ribeiro, a Europa sonhada pela Igreja "é a Europa na sua totalidade geográfica e na sua integridade humana e espiritual", e a unidade da Europa, mais do que política ou económica, é, sobretudo, um ideal de cultura e de civilização ${ }^{(62)}$. Isto significa que a evangelização da Europa se tornava não só o mais radical desafio aos europeus, mas também um esforço acrescido de solidariedade social ${ }^{(63)}$.

(61) Para além da Conferência Episcopal Portuguesa, também as Jornadas Diocesanas do Patriarcado de Lisboa e outros prelados, em Portugal, ou junto dos emigrantes em países estrangeiros, se preocuparam com a análise da integração de Portugal nas Comunidades Europeias. Veja-se Documentação Católica (D.C.), Lisboa, n. ${ }^{\text {os } 91-92, ~ J u l h o-A g o s t o, ~ 1985, ~ p p . ~ 1(245)-11(255) . ~ L e m b r e-~}$ -se também que na $2^{\mathrm{a}}$ reunião Plenária da COMECE realizada em Bruxelas, em 12 de Junho de 1980, uma das questões prioritárias da ordem do dia referia-se ao alargamento da Comunidade Europeia à Grécia, a Espanha e a Portugal. Na reunião de 6 e 7 de Novembro de 1981 está presente, como observador, D. José Policarpo, Bispo Auxiliar de Lisboa, que seria substituído pelo bispo D. Januário Torgal Ferreira, Bispo Auxiliar de Lisboa, eleito como representante da Conferência Episcopal Portuguesa, na COMECE, em Assembleia Plenária realizada em Fátima, de 28-29 de Junho de 1990, tendo sido reconduzido no cargo na Assembleia Plenária de 14-17 de Novembro de 1994. Cf. Conferência Episcopal Portuguesa. Documentos Pastorais, cit., vol. III, p. 321 e vol. IV, p. 370. Cf. Compte-rendus des réunions des 12-6-1980, et 6-7 novembre 1981, Bruxelles, COMECE (documentos dactilografados).

${ }^{(62) D o c u m e n t a c ̧ a ̃ o ~ C a t o ́ l i c a, ~ L i s b o a, ~ n . ~}{ }^{\circ}$ 91-92, Julho Agosto, 1985, pp. 4(248) e 5(249).

${ }^{(63)}$ Idem, ibidem, pp. 5(249)-7(251). 
Segundo D. José Policarpo, então Bispo Auxiliar de Lisboa e representante do episcopado português junto da COMECE, em carta dirigida a este organismo de Março de 1985, a inevitável dependência económica portuguesa das Comunidades Europeias e a possibilidade de uma crise de identidade histórica e cultural não eram suficientes para eliminar a esperança no futuro desenvolvimento do país. O país poderia, apesar disso, vencer a pobreza, a crise económica e, sobretudo, criar uma nova situação de dignidade, de igualdade de direitos, de respeito pela especificidade espiritual e cultural, em particular dos emigrantes portugueses residentes em vários países comunitários ${ }^{(64)}$.

Na linha de pensamento de João Paulo II, reevangelizar a Europa - afirmava D. José Policarpo no colóquio realizado em 1995, organizado pela COMECE, sobre La Construction Européenne et les Institutions Religieuses - constitui um elemento decisivo de edificação de uma comunidade europeia digna dos seus valores e das suas tradições. No fundo, só re-espiritualizando-se a Europa se poderiam vencer os malefícios éticos e sociais provocados pelo primado do económico. Dito por outras palavras, a reivindicação da defesa dos valores e da superioridade do espírito permitiria a formação, na Europa, "de uma consciência colectiva, de uma verdadeira opinião pública europeia". Com esta tese, D. José Policarpo atribuía um papel fundamental às Igrejas no plano social, cultural, espiritual, na abertura ao universal, na função educadora da Europa, da Europa global, da Europa do Atlântico aos Urais ${ }^{(65)}$. Assim, na sua perspectiva, a consumação do ideal de Europa definia-se na convergência de todas as componentes da sociedade: uma economia ao serviço do homem, o diálogo intercultural, a força das instituições comuns, o dinamismo das iniciativas da actividade social. Mas, sublinhava, na evolução deste percurso de crescente complexização, e para prevenir múltiplos e diversificados desajustamentos, a prioridade da cultura devia ser reconhecida. Cabia às Igrejas, às instituições religiosas, em particular ao cristianismo, religião de incarnação e factor de transformação e de intervenção na história dos homens, a salvaguarda da perenidade dos

${ }^{(64)}$ Carta de D. José Policarpo dirigida a Paul Huot-Pleuroux, de 10 de março de 1985, COMECE, Bruxelas, (documento dactilografado).

${ }^{(65)} \mathrm{D}$. José Policarpo, "L'avenir de l'Europe et les institutions religieuses", in La Construction Européenne et les Institutions Religieuses, Bruxelles, Bruylant-Academia, 1995, pp. 73-81. 
valores de solidariedade, reconciliação, justiça social, universalidade ${ }^{(66)}$. Com isto queria dizer que a influência do cristianismo sobre a sociedade não se limitaria, tão-só, à prática religiosa. Esta actuação insere-se na linha programática dos episcopados europeus que têm procurado fazer valer as aspirações da Igreja Católica num diálogo com os órgãos da União Europeia. Na sua Declaração sobre a Europa, de 1977, os bispos de Portugal, em união com outros bispos europeus, assumiram já essas responsabilidades no destino da Europa ${ }^{(67)}$.

É por isso que, três anos depois, em 1980, ao analisar a vivência de um tempo de insegurança, de inquietude, de incerteza, de novo os bispos europeus traçaram um itinerário crescentemente emancipador em que a visão transcendente se compaginava com uma política de realização concreta e positiva dos princípios do Evangelho. Por conseguinte, a acção da Igreja reafirmava-se na defesa intransigente dos direitos do homem, nas pretensões universalistas, na colaboração ecuménica, com vista a "uma Europa mais humana"(68). E estas mesmas directrizes encontramo-las nas reflexões e intervenções de D. Januário Torgal Ferreira, então Bispo Auxiliar de Lisboa, nas reuniões da COMECE, em que foi representante da Conferência Episcopal Portuguesa desde $1990^{(69)}$, muito em particular nos documentos apresentados sobre as eleições parlamentares (1994), as preocupações da Igreja em Portugal (1994) e sobre o alargamento da União Europeia (1997).

(66) Idem, ibidem, pp. 77-78.

(67) "Declaração sobre a Europa", in Conferência Episcopal Portuguesa. Documentos Pastorais, vol. I, 1967-1977, Lisboa, s.e., 1978, pp. 231-235 e Manuel Braga da Cruz, "A Igreja na transição democrática portuguesa", Lusitania Sacra, $2^{\text {a }}$ s., Lisboa, Revista do Centro de Estudos Religiosos, Universidade Católica Portuguesa, 8/9 (1996-1997), pp. 535-536.

${ }^{(68)}$ Declaração sobre as responsabilidades dos cristãos perante a Europa de hoje e de amanhã", in Conferência Episcopal Portuguesa, Documentos Pastorais, vol. II, 1978-1982, Lisboa, Secretaria Geral do Episcopado, 1983, pp. 124-134.

${ }^{(69)}$ Leia-se, entre outras, a sua intervenção sobre as "Preocupações da Igreja em Portugal", in Compte-rendus de la Réunion Plénière de la COMECE des 24-25 novembre, 1994, Luxembourg; Déclaration de la Commission des Épiscopats de la communauté européenne (COMECE) à l'occasion des Élections au Parlement Européen (Juin 1994) e Pour une Europe Unie. Élargissement de l'Union Européenne, COMECE, mai 1992. 
Por tudo o que ficou dito, e se integrarmos estas concepções e exegeses no quadro de uma antropologia cristã, isto significa que somente a dignidade do indivíduo e o seu papel na sociedade, segundo as premissas da subsidiaridade, solidariedade e equidade, poderão contribuir para "dar uma alma à Europa", segundo a conhecida expressão de Jacques Delors ${ }^{(70)}$.

\section{Conclusão}

À luz do que foi exposto, e no período que analisámos, pode concluir-se que o discurso protagonizado pelo Vaticano e pelos bispos da Igreja Católica é assumido explicitamente como um discurso cuja essência é de ordem ética, moral e social. Ainda que muitas vezes solicitada pelos Estados a pronunciar-se sobre questões não especificamente religiosas, a Santa Sé sem deixar de as pensar e debater, tem procurado, todavia, inseri-las num quadro de valores de natureza ética e espiritual.

O projecto da Santa Sé para a Europa na comunidade internacional especifica, dá configuração e determina uma unidade - a unidade religiosa que deve, em seu entender, preceder a unidade política. Isto é, o regresso aos valores cristãos, que é também a tomada de consciência de uma história e de uma cultura comuns, não pode contribuir, a seu ver, senão para atenuar as clivagens, para dirimir e vencer as hostilidades e fazer vingar a paz na Europa e no mundo. Em síntese, na angústia do pós-guerra, Pio XII formulou esse discurso, João XXIII reforçou-o com o seu conhecido profetismo, o espírito de diálogo de Paulo VI fundamentou-o e o Papa vindo de Leste, João Paulo II, tem-lhe vindo a dar maior consistência.

Esta Europa, que os pontífices e os episcopados consideram votada à união, não poderá ser, assim o reafirmam, produto exclusivo de um grande mercado ou da moeda única. A nova Europa, assim o entendem, deverá ser vivificada por uma cultura partilhada por todos. E nesta cultura, considera ainda a Santa Sé, o cristianismo tem não apenas um lugar, mas sobretudo uma acção importante a exercer. A Europa será, pois, na sua perspectiva, a força e o modelo para a evolução do mundo. Portadora da civilização, ou seja, dos valores cristãos, a Europa transforma-se, deste modo, e no pensamento da Santa Sé, num guia para a humanidade.

(70) Mgr Josef Homeyer (Président de la COMECE), "Allocution d'aventure", in La Construction Européenne et les Institutions Religieuses, cit., pp. 9-12. 
É esse, aliás, o sentido das palavras interpelativas de João Paulo II dirigidas à própria Europa: “Encontra-te a ti mesma... Reconstrói a tua unidade espiritual... Tu podes ser ainda um farol de civilização e um motor de progresso para o mundo"(71).

Neste horizonte, a Igreja Católica propõe-se cumprir a sua missão tradicional, a de educadora dos povos. Como procurámos mostrar, paralelamente à sua insistência em favorecer a cooperação das nações junto das instâncias comunitárias ou das negociações em prol da segurança, a Santa Sé criou organismos e estimulou uma acção diplomática de forma a consolidar as relações intereuropeias e a fomentar encontros ecuménicos. A verdade, porém, é que nas suas actividades multiformes e através de uma diplomacia omnipresente a Santa Sé intervém com objectivos de ordem política e de ordem espiritual. Por um lado, opera no sentido de um regulamento pacífico dos conflitos europeus, de um equilibrio geopolítico, e, por outro lado, lança o dado religioso na mesa das negociações internacionais, inserindo-o na problemática geral dos direitos do homem e na relação intrínseca com uma teoria cristã da paz. Com este objectivo, assume responsabilidades políticas ao defender a liberdade dos povos, ao condenar a absolutização da nação e os exacerbamentos etnocêntricos, ao salvaguardar a reafirmação das identidades nacionais. No quadro dos problemas da contemporaneidade, segundo a visão da Santa Sé, a construção política não pode deixar de ser uma reconstrução espiritual. E porque a Europa, segundo as palavras do Cardeal Solano, não é somente um mercado, mas tem uma alma e é uma fé, não pode negligenciar o seu múnus espiritual, ético e cultural que é, deste modo, na perspectiva vaticana, o único garante da solidez dos seus fundamentos políticos e sociais, sob pena de perder a sua própria alma. Em suma, a presença incisiva da Igreja romana no processo de reconstrução europeia pretende ser, como reitera, em última instância, como uma "memória viva" no processo de auto-revelação da Europa, o mesmo é dizer, no reencontro da sua própria essência ${ }^{(72)}$.

(71) Veja-se esta alocução de João Paulo II, de 9 de Novembro de 1982 em Santiago de Compostela, Cf. D.C., n 1842, 1982, p. 1129. Cf. Christine de Montclos-Alix, "Le Saint - Siège et l'Europe", in Le Saint - Siège et les relations internationales, cit., pp. 159 e 161.

(72) Joël-Benoît d'Onorio, "L'Église, mémoire vivante del'Europe", in Le Vatican et la politique européenne, Paris, Mame, 1994, pp. 294-310. 